\title{
TO COMPARE THE FUNCTIONAL OUTCOME OF INTRA ARTICULAR DISTAL END OF RADIUS FRACTURE TREATED BY CONVENTIONAL POP CAST AND EXTERNAL FIXATATOR FIXATATION
}

\author{
Gupta $P K^{1^{*}}$, Chaudhary $A K^{2}$
}

\section{Affiliation}

1. Assistant Professor, Department of Orthopedics, Birat Medical College Teaching Hospital, Biratnagar, Nepal.

2. Lecturer, Department of Orthopedics, Birat Medical College Teaching Hospital, Biratnagar, Nepal.

\section{ARTICLE INFO}

\section{Article History}

$\begin{array}{ll}\text { Received } & \text { 28 July, } 2018 \\ \text { Accepted } & : \text { 19April, } 2019 \\ \text { Published }: & 30 \text { April, } 2019\end{array}$

(C) Authors retain copyright and grant the journal right of first publication with the work simultaneously licensed under Creative Commons Attribution License CC - BY 4.0 that allows others to share the work with an acknowledgment of the work's authorship and initial publication in this journal.

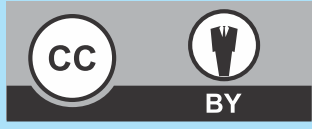

ORA 95

DOI: http://dx.doi.org/10.3126/bjhs.v4i1.23927

\section{* Corresponding Author \\ Dr. Pradip Kumar Gupta Assistant Professor \\ Department of Orthopedics}

Birat Medical College Teaching Hospital, Biratnagar, Nepal Email:pkgupta_22@yahoo.com

Orcid ID : https://orcid.org/0000-0003-1056-7070

\section{Citation}

Gupta PK, Chaudhary AK. To Compare The Functional Outcome of Intra Articular Distal end of Radius Fracture Treated by Conventional Pop Cast and External Fixatator Fixatation. BJHS 2019;4(1)8: 586 - 591.

\section{ABSTRACT}

\section{Introduction}

Distal end of radius fractures frequently have a high degree of comminution, instability, and associated with soft tissue injuries. Treatment of this distal radius fracture is controversial and there is no single definitive treatment method that is considered the standard of care.

\section{Objective}

1. To compare the functional results of the conventional POP cast and external fixator fixation of intra articular distal end of radius fracture.

2. To compare the radiological changes with that of functional outcome.

\section{Methodology}

It was a prospective study comparing the functional outcome of distal intra-articular radius fracture when managed by conventional POP cast and external fixatator fixation. The final outcome was decided on the basis of modified Gartland and Werley scoring system. Total 50 patients ( $19-54$ years) were recruited. 30 were treated by closed reduction and POP cast and 20 by external fixation. Radiological parameters were graded according to Schecks criteria and fracture comminution was classified according to Frykman's classification.

\section{Results}

The functional outcome of the treatment was a subjective evaluation in which $80 \%$ of the patients had pain in external fixation as compared to $63 \%$ in closed reduction POP cast group. The restriction of activities was in $10 \%$ of the patient in external fixation group as compared with $33 \%$ in closed reduction POP cast group. The final scoring system as modification of Gartland and Werley point system had $5 \pm 3$ conventional pop cast group and $4 \pm 4$ in external fixation group. ( $p=0.3764)$. On radiological evaluation, there was no significant difference in radial length, radial angle and volar tilt in two groups.

\section{Conclsion}

The results show no statistically significant difference between the two modes of interventions. External fixation provides easy mobilization of fingers and reduces edema and stiffness of joints. The active ranges of movements at the wrist joints were significantly better in external fixation group.

\section{KEY WORDS}

Fractures, distal end radius, intra-articular, conventional POP cast and external fixator. 


\section{INTRODUCTION}

Distal end of radius fractures account for $14 \%$ of all extremity injuries and $17 \%$ of all fractures treated in the emergency department. ${ }^{1}$ Distal radius fractures occurring as a result of a high-energy injury represent a subset of fractures, often with significant injury and impairment to the upper extremity. These fractures frequently have a high degree of comminution, instability, and associated with soft tissue injuries.

Distal radius fractures crush the mechanical foundation of man's most elegant tool, the hand. No other fracture has a greater potential to devastate hand function and no metaphysis of bone is embraced by more precious soft tissues. It is remarkable that this common fracture remains one of the most challenging of all fractures that are treated non-operatively. Many physicians believe that no special treatment is needed as the resulting deformity rarely results in loss of function. However this concept is being increasingly challenged.

A consensus exists that although minimally displaced stable fractures usually can be managed successfully by closed methods of treatment; unstable articular fractures frequently require more invasive techniques to maintain an accurate reduction during the healing process. Foremost among these techniques is external fixation employing the concept of continuous distraction, commonly termed ligamentotaxis. Ligamentotaxis neutralizes the deprimental compression forces, which are likely to cause displacement of unstable articular fracture components leading to progressive radial shortening. It is a significant advancement in the management of distal radius fractures.

Treatment of distal radius fracture is controversial; there is no single definitive treatment method that is considered the standard of care. Most studies are retrospective in nature and use various classification and inconsistent outcome tools, especially in regard to comminuted fractures with joint incongruity.

In an epidemiology survey of all fractures of the forearm that were treated over a 5-year period in Malmo, Sweden, Alffram ${ }^{2}$ and Bavar recorded nearly 2000 fractures of the distal end of radius, which was $74.5 \%$ of all fractures of the forearm.

\section{OBJECTIVES}

1. To compare the functional outcome of the following aspect amongst patients treated by closed reduction POP cast and External fixator fixation of intra articular distal end of radius fractures.

a) Subjective evaluation-Pain, Loss of movement, Weakness and Restriction of activities.

b) Range of movement- Palmar flexion, Dorsi flexion, Ulnar deviation, Radial deviation, Supination and Pronation.

c) Grip strength

2. To compare the following aspect amongst radiological changes with that of the functional outcome.Radial length, Radial angle, Volar tilt, and Distal radio-ulnar joint distance.

\section{METHODOLOGY}

This was prospecti-ve study of either sex, having closed intra-articular fractures of distal end of radius. A total of 50 patients, (19-54 years), were selected among them 30 patients were treated by closed reduction and POP cast and 20 underwent through external fixation. The study was conducted at Birat Medical College, Biratnagar, Nepal from June 2014 to May 2016. Approval of the study was obtained from the institutional ethical committee. Informed and written consents were obtained from the patient and patient relatives. Pre operative evaluation was done in both groups which include history regarding the mode of injury, clinical and radiological assessment. Radiological assessment of fracture pattern was assessed with antero-posterior(AP)/ posterior -anterior(PA) and lateral radiographic views of the wrist. The fracture pattern was classified according to Frykman's classification. Radiographic assessment also includes radial length, radial angle and volar tilt.

The radial length (radial height) is measured on the PA view radiograph as the distance between one line perpendicular to the long axis of the radius passing through the distal tip of the radial styloid. A second line intersects distal articular surface of ulnar head.

The radial angle (radial inclination) represents the angle between two lines-one drawn perpendicular to the long axis of the radius at the ulnar corner of the lunate fossa and the other between that point in the lunate fossa and the tip of radial styloid. This was measured on the PA view of radiograph.

The volar tilt (radial tilt) represents the angle between a line along the distal radial articular surface and the line perpendicular to the longitudinal axis of the radius joint margin. This was measured on the lateral view of radiograph.

The patient with previous deformity of the same limb, mentally retarded patients with osteoporosis of the bone and previous surgery at the same site and neurovascular injuries were excluded.

Closed reduction and POP cast immobilization group: fractures were reduced under sedation or hematoma block and below elbow or above elbow plaster of Paris (POP) cast was applied. Most of the patients were given cast in palmar flexion and ulnar deviation of the wrist but some were given cast in dorsiflexion position after evaluating the fracture pattern Frykman type VII fractures had volarly displaced. The volarly displaced Volar Barton fractures were given the cast above elbow in dorsiflexion position. Patients were called after 24 hours for inspection to assess distal circulation, swelling and tightness of plaster cast. Plaster cast was applied for 5 to 6 weeks depending upon clinical and radiological union. Reduction was attempted again in selected cases in which fracture re-displaced within 10 days of initial closed reduction.

External fixator fixation group: - The Bridging external fixator was used to achieve ligamentotaxis effects. On the first post-operative day active and assisted range of motion of the fingers, forearm, elbow and shoulder was started. The 
post-operative dressing was removed after two days, and patients were instructed regarding the care of pin sites.

$\mathrm{X}$-rays were taken immediately after surgery, at 2 weeks and then after 6 weeks to assess the fracture alignment and union. Fixator was removed after clinical and radiological evidence of union. On outpatient basis below elbow cast was given for another 2 weeks to prevent fracture through the pin sites. Patients were advised to undergo physiotherapy for 6 to 8 weeks following removal of fixators.

In the both groups the final assessment of the functional end results in the present series was based on a clinical examination carried out in accordance with a predetermined plan i.e. (swelling, tenderness, active mobility of the wrist, grip strength and distance between the pulp of the fingers and the palm).

Radiological evaluation - antero-posterior and lateral radiograph were taken at the time of injury, immediately after reduction, at 2 weeks and at time of last follow up which was at 6 months. Measurements of radial length, radial angle and volar tilt were measured. Also the distance between the distal end of the radius and ulna at the level of the distal radio-ulnar joint was measured.

Chi-square test was used to analyze the categorical data while student $t$ test was used for continuous

data for comparing the final outcome of the functional end results on the basis of modified Gartland and Wereley scoring system. ${ }^{3}$ Statistical analysis was done using EPI Info 2000 software. $P<0.05$ was considered as statistically significant.

\section{RESULTS}

The average age of the patients was $34 \pm 11$ years in closed reduction pop cast group and $33 \pm 8$ years in external fixator group. The frequency of sex in our study was male 38(76\%) and female $12(24 \%)$.

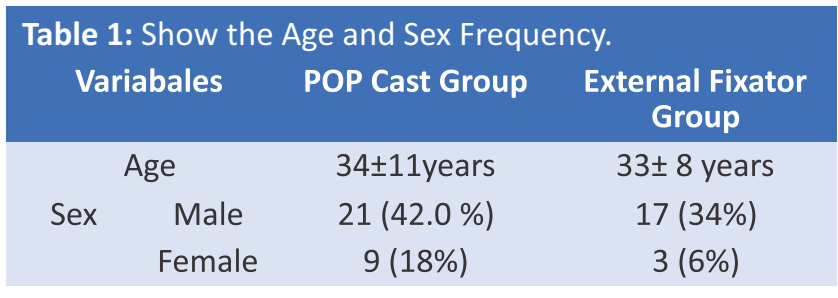

The most common cause of the distal end of radius fracture in our study was FOOSH (56\%) followed by RTA. Table 2 shows the modes of injury encountered in our study.

\begin{tabular}{ccc|}
$\begin{array}{c}\text { Table 2: Mode of Injury } \\
\text { Mode }\end{array}$ & No. of Patients & \%age \\
\hline RTA & 22 & $44 \%$ \\
FOOSH & 28 & $56 \%$ \\
Total & 50 & 100 \\
\hline
\end{tabular}

(RTA- road traffic accident, FOOSH-fall on out stretch hand)

The most common type and sides of fractures were as mentioned in Table III and IV respectively.

\begin{tabular}{ccccccc} 
Table 3: Fracture Classification (Frykman's Grade) $n=50$ \\
Type & $\begin{array}{c}\text { Close reduction POP cast } \\
\text { Number }\end{array}$ & $\begin{array}{c}\text { External fixation } \\
\text { Number }\end{array}$ & $\%$ & Total & $\%$ \\
\hline III & 4 & 13.33 & - & & 4 & 8.00 \\
IV & 3 & 10.00 & - & & 3 & 6.00 \\
V & 1 & 3.33 & - & & 1 & 2.00 \\
VI & 2 & 6.67 & 1 & 5.00 & 3 & 6.00 \\
VII & 10 & 33.33 & 9 & 45.00 & 19 & 38.00 \\
VIII & 10 & 33.33 & 10 & 50.00 & 20 & 40.00 \\
Total & 30 & 100.00 & 20 & 100.00 & 50 & 100.00
\end{tabular}

\begin{tabular}{|c|c|c|c|c|c|c|}
\hline \multirow[t]{2}{*}{ Side Involved } & \multicolumn{2}{|c|}{$\begin{array}{l}\text { Close reduction } \\
\text { POP cast }\end{array}$} & \multicolumn{2}{|c|}{ External fixation } & \multirow[b]{2}{*}{ Number } & \multirow[b]{2}{*}{$\%$} \\
\hline & Number & $\%$ & Number & $\%$ & & \\
\hline Dominant & 16 & 53.33 & 11 & 55.00 & 27 & 54.00 \\
\hline Non dominant & 14 & 46.67 & 9 & 45.00 & 23 & 46.00 \\
\hline Total & 30 & 100.00 & 20 & 100.00 & 50 & 100.00 \\
\hline
\end{tabular}

Table 5: Subjective, Range of Movement and Grip Strength

\section{Evaluation}

\begin{tabular}{|c|c|c|c|c|}
\hline & & POP Cast & $\begin{array}{l}\text { External } \\
\text { Fixation }\end{array}$ & P Value \\
\hline \multirow{4}{*}{ Subject Evaluation } & Pain & $63.3 \%$ & $80.0 \%$ & \\
\hline & Loss of movement & $66.7 \%$ & $65.0 \%$ & \\
\hline & Weakness & $33.3 \%$ & $20.0 \%$ & \\
\hline & Restriction of activities & $33.3 \%$ & $10.0 \%$ & \\
\hline \multirow{6}{*}{ Range Of Moment } & Palmar Flexion & $56 \pm 12 \circ$ & $59 \pm 13$ 은 & 0.5 \\
\hline & Dorsi Flexion & $46 \pm 160$ & $60 \pm 12^{\circ}$ & 0.004 \\
\hline & Ulnar deviation & $15 \pm 40$ & $21 \pm 50$ & 0.0001 \\
\hline & Radial deviation & $14 \pm 4$ 은 & $19 \pm 3$ 은 & 0.0008 \\
\hline & Supination & $72 \pm 80$ & $81 \pm 10$ 은 & 0.0017 \\
\hline & Pronation & $69 \pm 80$ & $81 \pm 90$ & 0.0001 \\
\hline \multirow{3}{*}{ Grip Strength } & Normal Hand & $25 \pm 4 \mathrm{Kg}$ & $27 \pm 2 \mathrm{Kg}$ & 0.0169 \\
\hline & Injured Hand & $21 \pm 4 \mathrm{Kg}$ & $20 \pm 3 \mathrm{Kg}$ & 0.9656 \\
\hline & $\begin{array}{l}\text { Difference Normal to } \\
\text { Injured Hand }\end{array}$ & $4 \pm 2 \mathrm{Kg}$ & $6 \pm 3 \mathrm{Kg}$ & 0.0306 \\
\hline
\end{tabular}

Table 6: Radiological Evaluation

\begin{tabular}{|c|c|c|c|c|c|c|c|c|c|}
\hline & \multicolumn{3}{|c|}{ Before Treatment } & \multicolumn{3}{|c|}{ After Treat ment } & \multicolumn{3}{|c|}{ Difference } \\
\hline & Pop Cast & $\begin{array}{c}\text { Ext. } \\
\text { Fixator }\end{array}$ & P value & Pop cast & Ext. Fixator & P Value & Pop Cast & Ext Fixator & $P$ value \\
\hline Redial Length & $6 \pm 3 \mathrm{~mm}$ & $5 \pm 5 \mathrm{~mm}$ & 0.4472 & $8 \pm 2 \mathrm{~mm}$ & $10 \pm 4 \mathrm{~mm}$ & 0.1319 & $-2.4 \pm 3 \mathrm{~mm}$ & $-4.7 \pm 4 \mathrm{~mm}$ & 0.0386 \\
\hline Redial Angle & $17 \pm 60$ & $14 \pm 12 \circ$ & 0.2864 & $20 \pm 3 ㅇ$ & $19 \pm 70$ & 0.5577 & $-3.0 \pm 60$ & $-5.0 \pm 12 \circ$ & 0.4794 \\
\hline Volar Tilt & $-5.1 \pm 13 ㅇ$ & $0.3 \pm 13 ㅇ$ & 0.1725 & $0.26 \pm 90$ & $10 \pm 8^{\circ}$ & 0.0004 & $-5.0 \pm 12 \circ$ & $-9.0 \pm 150$ & 0.2512 \\
\hline $\begin{array}{l}\text { DRUJ } \\
\text { Distance }\end{array}$ & & & & $2.1 \pm 1.1 \mathrm{~mm}$ & $1.3 \pm 1.8 \mathrm{~mm}$ & 0.0886 & & & \\
\hline
\end{tabular}

\section{Final Score}

The final scoring system was as modification of Gartland and
Werley point system had $5 \pm 3$ in closed reduction pop cast group and $4 \pm 4$ in external fixation group. $(p=0.3764)$ 


\section{DISCUSSION}

Thirty Years ago, the distal end of radius fractures were considered benign and conservative treatment was the rule. The population involved supposed consisted of osteoporotic old women who were functionally satisfied despite poor results and exact reduction was not mandatory, since good results were not said to be correlated with good reduction. Cosmetic deformity from malunion were noticed, but deemed unimportant.

Since then, growing number of young male workers and sports enthusiasts have suffered high velocity injuries, often resulting in complex intra-articular fractures. Pain and disability have resulted from subsequent malunions. Redisplacement or loss of reduction after conservative treatment is another feature which was not well recognized in the past. This factor of re-displacement was also overlooked for a long time.

As the Orthopedic community recognizes the complexity of this injury and focus attention on the anatomical restoration that is important for optimal function, a variety of treatment options are being investigated. Regardless of age of patient, vocation or recreational interest, therapies are sought to maximize the potential for pain-free motion and acceptable cosmetic results. achieved in our study fits within both these ranges.

Radiological criteria for success includes the radial length (radial height) in PA view measurement averages $10-13 \mathrm{~mm}$, Radial angle (radial inclination) in PA view measurement averages $210-250$ and volar tilt (radial tilt) in Lateral view measurement averages 11․ Studies have shown that the radial length is the single most important factor affecting the final outcome. Loss of radial length results in an attenuation in weight transmission across the wrist joint, manifested by limited rotation of the forearm and impingement of the ulna and radius. Since the classic paper of Knirk and Jupiter ${ }^{13}$ which demonstrated that the largest tolerable articular step was $2 \mathrm{~mm}$, numerous articles have appeared demonstrating that the long term outcome of treatment of intra-articular fracture depends more on integrity of the articular surface than on any other measures.

Radiological parameters were measured and graded according to Schecks ${ }^{14}$ criteria. Our study showed average radial length was $8 \pm 2 \mathrm{~mm}$ in closed reduction POP cast group and $10 \pm 4$ $\mathrm{mm}$ in external fixation group, radial angle was $20 \pm 3$ o in closed reduction POP cast group and $19 \pm 70$ in external fixation group and volar tilt was $0.26 \pm 9$ o in closed reduction POP cast group and $10 \pm 8$ o in external fixation group. These comparison shows that the radiological parameters of our study vs. others studies which is shown in table 8.

\begin{tabular}{|c|c|c|c|c|c|c|c|c|c|}
\hline Authors and years & $\begin{array}{c}\text { Number } \\
\text { of } \\
\text { Patients }\end{array}$ & $\begin{array}{c}\% \text { of I/A } \\
\text { involve- } \\
\text { ement }\end{array}$ & $\begin{array}{l}\text { Treatment } \\
\text { method }\end{array}$ & $\begin{array}{l}\text { Dorsi } \\
\text { flexion }\end{array}$ & $\begin{array}{l}\text { Palmar } \\
\text { flexion }\end{array}$ & $\begin{array}{c}\text { Radial } \\
\text { Devi-ation }\end{array}$ & $\begin{array}{c}\text { Ulnar } \\
\text { Devi-ation }\end{array}$ & Pronation & Supination \\
\hline Cooney ${ }^{5} 1979$ & 60 & 88 & Ext. Fix. & 580 & $52^{\circ}$ & $18^{\circ}$ & 30 은 & 80 은 & 750 \\
\hline Cooney et al ${ }^{6} 1980$ & 100 & NA & Ext. Fix. & $50 \circ$ & 480 & 9o & 260 & $73 \circ$ & 700 \\
\hline Foster et al & - & - & Ext. Fix. & 470 & $59 \circ$ & $22^{\circ}$ & $32 \circ$ & - & - \\
\hline Foster et al & - & - & Ext. Fix. & 580 & 560 & 260 & $33 ㅇ$ & - & - \\
\hline Gairon et al & - & - & - & 55 응 & 460 & $11 ㅇ$ & 19 은 & 80 & $71 ㅇ$ \\
\hline Nakata et al 1985 & - & - & - & $77 \%$ & $77 \%$ & $73 \%$ & $82 \%$ & $84 \%$ & $78 \%$ \\
\hline Vaughan et al ${ }^{8} 1985$ & 52 & 100 & Ext. Fix. & 54 & 48 & 19음 & 32 & 80 & 78 \\
\hline Jack Lennox et al 1989 & 20 & NA & Ext. Fix. & $54.7 ㅇ$ & 55.9 & $19.4 ㅇ$ & 29.60 & 65.2 & $71.2^{\circ}$ \\
\hline Edwards et al 1991 & 30 & 100 & Ext. Fix. & 70 & 649 & 190 & 270 & $83 ㅇ$ & $90 \circ$ \\
\hline Fernandez et al ${ }^{9} 1991$ & 40 & 100 & Various & 63 & 60 은 & 10 은 & 250 & 770 & 73으 \\
\hline Kaemffe et al 1993 & 26 & NA & Ext. Fix. & 550 & $39 \circ$ & $17^{\circ}$ & $25 ㅇ$ & $84 ㅇ$ & 780 \\
\hline Zanotti et al ${ }^{10} 1997$ & 25 & 100 & Ext. Fix. & $58 ㅇ$ & 660 & 19 & 290 & $90 \circ$ & 770 \\
\hline $\begin{array}{l}\text { Persent study pop cast } \\
\text { group }\end{array}$ & 30 & 100 & POP & $46 \pm 160$ & $56 \pm 12^{\circ}$ & $14 \pm 4$ 응 & $15 \pm 40$ & $69 \pm 80$ & $72 \pm 80$ \\
\hline $\begin{array}{l}\text { Present study external } \\
\text { fixation group }\end{array}$ & 20 & 100 & Ext. Fix. & $60 \pm 12 \circ$ & $59 \pm 13$ & $19 \pm 3$ & $21 \pm 5$ 은 & $81 \pm 90$ & $81 \pm 10$ 은 \\
\hline
\end{tabular}

Fractures in the distal end of the radius has been estimated to account for more than one-sixth of all fractures seeing and treated in emergency department ${ }^{4}$

After reviewing the articles (Table 7) on the treatment of intra-articular distal end of radius fractures we didn't find any prospective study while comparing the two methods of treatment.

Palmer et al $^{11}$ conducted after an extensive study of activities of living ( $A D L)$. The normal functional wrist range of movement was 5을 deviation, and 15 o of ulnar deviation. Ryu et al $^{12}$ in a similar study concluded that ADL could be accomplished with $70 \%$ of maximal wrist motion, or 40 ㅇ of flexion, 40 o of extension, and 40 of combined radial and ulnar deviation. The ranges
Table 8: Comparison of Radiological Parameters

\begin{tabular}{|c|c|c|c|c|}
\hline $\begin{array}{l}\text { Authors } \\
\text { \& Year }\end{array}$ & Treatment & Radial Length & $\begin{array}{l}\text { Radial } \\
\text { Angle }\end{array}$ & $\begin{array}{l}\text { Volar } \\
\text { Tilt }\end{array}$ \\
\hline $\begin{array}{l}\text { Schuind et al }{ }^{15} \\
1989\end{array}$ & Ext. Fix. & $10.7 \mathrm{~mm}$ & 22.19 & $2.8^{\circ}$ \\
\hline $\begin{array}{l}\text { Zanotti and } \\
\text { Louis }^{10} 1997\end{array}$ & Ext. Fix. & $13 \mathrm{~mm}$ & $20.1^{\circ}$ & $3.5^{\circ}$ \\
\hline $\begin{array}{l}\text { D'Anca et al } \\
1984\end{array}$ & Ext. Fix. & $6 \mathrm{~mm}$ & 200 & 29 \\
\hline Jarry Gainor & Ext. Fix. & $12 \mathrm{~mm}$ & 180 & 3음 \\
\hline $\begin{array}{l}\text { Jack Lennox } \\
1989\end{array}$ & Ext. Fix. & $10.4 \mathrm{~mm}$ & 21.250 & $1.5 \circ$ \\
\hline Agee et al & Ext. Fix. & $12.5 \mathrm{~mm}$ & $18.7^{\circ}$ & 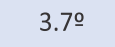 \\
\hline Our Study & Pop cast & $\begin{array}{c}8 \pm 2 \mathrm{~mm} \\
10+4 \mathrm{~mm}\end{array}$ & $\begin{array}{l}20 \pm 30 \\
19+70\end{array}$ & $\begin{array}{c}0.26 \pm 99 \\
10+80\end{array}$ \\
\hline
\end{tabular}


The radiological parameters were compared with that of functional outcome. In our study $85 \%$ of the patients had good to excellent radiological parameters according to the functional outcome. Out of the 3 parameters volar tilt was the least important factor in the functional outcome.

The functional outcome of the treatment is subjective evaluation to which the pain had $80 \%$ in external fixation group as compared to $63 \%$ in closed reduction pop cast group. The restriction of activities had $10 \%$ in external fixation group as compared with $33 \%$ in closed reduction pop cast group.

Since patient with external fixation could use their hand for routine activities, incidence of finger stiffness was very low. However they required good physiotherapy under supervision during initial period of management. In the past majority of complication in the fixation group were due to

\section{CONCLUSION}

The results show no statistically significant difference between the two modes of interventions.

External fixation provides a better mode of treatment for comminuted intra-articular fracture of distal end radius as compared to conventional POP cast immobilization. It provides easy mobilization of fingers and reduces edema and stiffness of joints. The active range of movements at the wrist joints was significantly better in external fixation group.

\section{RECOMMENDATIONS}

The treatment of intra articular distal end radius fracture is controversial. There is no definitive treatment method which is considered the standard of care.

\begin{tabular}{|c|c|c|c|c|c|c|}
\hline Complication & $\begin{array}{l}\text { Sanders RA } \\
\text { et al }{ }^{20} 1991\end{array}$ & $\begin{array}{c}\text { Weber et al } \\
1986\end{array}$ & 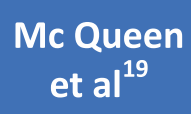 & $\begin{array}{c}\text { Vaughan } \\
\text { et al }\end{array}$ & $\begin{array}{l}\text { Foster } \\
\text { et al }\end{array}$ & $\begin{array}{c}\text { Present } \\
\text { Study }\end{array}$ \\
\hline Pin Tract Infection & 8 & 6 & 1 & 1 & 3 & 5 \\
\hline Pin Tract Osteomyelitis & 2 & 3 & 1 & - & 3 & - \\
\hline Loose Pins & 2 & 16 & - & 1 & - & - \\
\hline Broken Pins & 2 & - & - & 1 & - & - \\
\hline Loss of Reduction & 17 & 10 & NA & NA & - & 2 \\
\hline Radial Nerve Injury & 7 & 2 & 1 & 2 & - & - \\
\hline Carpal Tunnel Syndrome & 2 & - & 5 & - & 1 & - \\
\hline Finger Stiffness & 8 & - & 1 & - & - & - \\
\hline ECR Tendinitis & 1 & - & - & - & - & - \\
\hline latrogenic Fracture & - & 5 & - & 1 & 1 & - \\
\hline Non-union & - & 3 & - & - & - & - \\
\hline Mal-union & - & - & - & - & - & 1 \\
\hline RSD & - & - & 1 & - & - & - \\
\hline Compartment Syndrome & - & - & 1 & - & - & - \\
\hline Arthritis & 1 & - & - & - & - & - \\
\hline
\end{tabular}

the pins infection. Since we were using limited open surgical technique, threaded pins and better construct for fixation, the complications were avoided. In the study by Henrik $G$ Ahlborg et al $^{16}$, there were $27 \%$ pin related complications out of 314 fractures treated with external fixation. The same percentage of complication was found in the study of Howard PW et al ${ }^{17}$, Soren Solgaard ${ }^{18}$ and McQueen et al. ${ }^{19}$

Fractures through pin site is an uncommon complication with reported rates of $0-20 \%$ Vaughan et al ${ }^{8}$, Schuind et al. ${ }^{15}$

In our study five were found pin tract infection out of 80 pins in external fixator group. These infections were superficial and healed on antibiotics and didn't cause any changes in the progression of the healing of the fractures.

The complication comparison of external fixatation of our study vs others studies are shown in table 9.

\section{LIMITATION OF THE STUDY}

This study would have been more informative if we had included the percutaneous pinning and internal fixation with plate.

\section{ACKNOWLEDGEMENTS}

We extend our sincere gratitude to the Department of Orthopaedics faculty members of Birat Medical College, Biratnagar for their support to conceptualize this article.

\section{CONFLICT OF INTEREST}

None declared.

FINANCIAL DISCLOSURE

None 


\section{REFERENCES}

1. Gellman, H: Fracture of the distal radius. American Academy of orthopedics surgeons monographs series. Rosemont, IL, American Academy of orthopedic surgeons, 1998.

2. Alffram PA, Bauer GCH: Epidemiology of Fractures of the forearm. A biomechanical investigation of bone strength. JBJS (Am) 44A; 105 114, 1962. PMID-14036674

3. Gartland JJ Jr, Werley, CW: Evaluation of healed colles' fractures. JBJS Am, 3(A); 895-907, 1951.PMID-14880544

4. Owen RA, Melton L J, Johnson KA, Ilstrup DM, Riggs BL: Incidence of Colles' Fracture in a North Community, Am J. Pub. HealAmerican Cth 72;605-607 1982. PMID- 7072880.

5. Cooney WP, Linscheid RL and Dobyns JH: External Pin fixation for unstable colles' fractures. JBJS Am 61(6A), 840 - 845, 1979. PMID6155380.

6. Cooney WP, Dobyns, JH and Linscheid RL: Complications of colles' fractures. JBJS (Am), 62(4), 613-619, 1980. PMID-6155380.

7. Nakata RY, Chand Y, Matiko JP et al: External fixators for wrist fractures. A biomechanical and clinical study, J. Hand Surg $10 \mathrm{~A}$; 845-51, 1985. PMID-4078267.

8. Vaughan PA, Lui SM, Harrington, IJ et al: Treatment of unstable fractures of the distal end of radius by external fixator. JBJS Br, 67(3), 385-9, 1985.PMID-3997946.

9. Fernandez, DL: Fracture of the distal radius - operative treatment. AO's Instructional Course Lecturers, 42, $73-88$, 1993. PMID8463706.

10. Zanotii RM, Louis DS: Intra articular fractures of distal end of radius treated with an adjustable fixator system. J. Hand Surg Am. 22(3); 428-440, 1997. PMID-9195451.

11. Palmer AK, Werner FW et al: Functional wrist motion - a biomechanical study. J. Hand Surg Am. 10(1): 39-46, 1985. PMID3968403.
12. Ryu JY, Cooney WP, Askew LJ, An KN, Chao EYS- Functional ranges of motion of the wrist joint. J Hand Surg (Am) 1991, May, 16 (3), 409- 19. PMID- 1861019

13. Knirk, JL, Jupiter, JB: Intra-articular fractures of the distal end of the radius in young adults. JBJS (Am), 68, 647-659, 1986. PMID-3722221.

14. Scheck, M: Long term follow up of treatment comminuted fractures of the distal end of the radius by Tran's fixation with krischner wires and cast. JBJS Am, 44-A, 337-51, 1962. PMID-14039000.

15. Schuind F, Donkerwolcke M, Rasquin C, Burny F. External fixation of fractures of the distal radius. A study of 225 cases. J Hand Surg (Am) 1989; 14:404-407. PMID-2732436.

16. Henrik G Ahlborg \& Per Olof Josefsson : Pin-tract complications in external fixation of fractures Of the distal radius, Acta Orthopaedica Scandinavica 70:2, 116-118,1999. PMID-10366908.

17. Howard PW, Stewart HD, Hind RE et al: External fixation or plaster for severely displaced comminuted colles' fracture: A prospective study of anatomical and functional results. JBJS Br 71(1), 68-73, 1989.PMID2915010.

18. SøRen Solgaard, Bjarne Kristiansen \& JøRgen Steen Jensen: Evaluation of instruments for measuring grip strength, Acta Ortho Scand 55, 569 -572, 1984. PMID-6507083

19. McQueen, $M$, Caspers, and J: Colles' fracture: Does Anatomic results affect the final function? , JBJS 70-B, 649, 1988. PMID- 3403617

20. Sanders RA, Keppel FL, and Waldrop JI: External fixation of Distal radial fracture: Result and Complications. J Hand Surg. 16-3, 385-391, 1991.PMID-1861015

21. Weber SC, Szabo RM: Severely comminuted distal radial fractures as an unsolved problem. Complications associated with external fixators and pins and plaster techniques. J Hand Surg. 11-A, 157 - 165, 1986. PMID-3958443 